\title{
Assessment of water environment risk management technology in the watershed during the "Thirteenth Five-Year Plan" period in Liaoning Province based on the analytic hierarchy process
}

\author{
Yafeng Li, Jianbo $\mathrm{Wu}^{*}$, and Yanchen Shang \\ School of Municipal and Environmental Engineering, Shenyang Jianzhu University, Shenyang1 10000, China
}

\begin{abstract}
This paper uses the analytic hierarchy process (AHP) as the basic framework, and evaluates the water environment risk management technology of the river basin in Liaoning Province, so as to scientifically and reasonably measure the advantages and disadvantages of the existing technology.The research results show that the best technical indicator is the research management technology of water environment quality monitoring technology; the best environmental indicator is the management technology of the research project of water quality safety assessment and early warning management technology in the basin. The highest overall score is the water environment quality monitoring technology method research management technology. Each management technology has certain advantages, and the management technology should be used jointly.
\end{abstract}

\section{Introduction}

The Liao River Basin is one of the areas in China where cities are concentrated, densely populated, and socially and economically developed. Under the dual pressure of high-intensity economic development and relatively lagging environmental management, the problems of water pollution and ecological deterioration have become economic and social sustainable in the region. The main constraints of development [1].Risk assessment is to identify and measure the possible loss of human health, social and economic development, ecosystems, etc. caused by or faced by various human development activities (including natural disasters). It includes sudden water environment risk assessment and cumulative water environment risk assessment [2].Sudden water pollution accidents mainly refer to accidents caused by accidents, where a large amount of pollutants enter the water body in a short time, which causes rapid deterioration of water quality, affects the effective use of water resources, seriously affects normal economic and social activities, and destroys the water ecological environment. Cumulative environmental risk means that after long-term accumulation of trace pollutants in human development activities to a certain extent, it will produce rapid ecosystem degradation or cumulative toxic effects, and ultimately endanger human health[3]. This risk has no obvious manifestation in the short term, but it has a long-term impact on human health and ecological security [4].
Liao River Basin water environment risk management technology includes: Through objective, scientific and reasonable evaluation of these management technologies, a series of post-evaluation mechanisms for river basin ecological protection policies are formulated to promote the development of postevaluation mechanisms for national river basin ecological protection policies.

\section{Materials and Methods}

\subsection{TestMethod}

According to the characteristics of the technology to be evaluated, the indicators are preliminarily selected, and the analytic hierarchy process index system is established, including three levels. The first level is the criterion level (A) including technical indicators, economic indicators, and environmental indicators: the second level, the evaluation level (B), includes several indicators; the third level, the index level (C), includes several indicators. The analytic hierarchy process is used to assign weights to the criterion layer and the evaluation layer.

ProfessorSaaty'snine-digit ratioscale is used to compare the importance of the three indicators of the first level of criteria levels A1, A2 and A3 [5]. By analyzing the relative importance of the first-level indicators $\mathrm{A} 1$ to $\mathrm{A} 3$ at the criterion level, the judgment matrix shown in the following table 1 can be obtained.

*Corresponding author:627311308@qq.com 
Table 1. Judgment matrix of the importance of each index

\begin{tabular}{|c|c|c|c|}
\hline & A1 & A2 & A3 \\
\hline A1 & 1 & $1 / 3$ & 5 \\
\hline A2 & 3 & 1 & 7 \\
\hline A3 & $1 / 5$ & $1 / 7$ & 1 \\
\hline
\end{tabular}

Check the consistency of the constructed judgment matrix, and calculate the consistency index value $\mathrm{CI}=(\lambda \max -n) /(\mathrm{n}-1)$ and $\mathrm{CI}=\mathrm{CI} / \mathrm{RI}$. Among them, $\lambda \max$ is the largest characteristic root of the judgment matrix, $n$ is the matrix dimension, and RI is the average random consistency index. If $\mathrm{CR}<0.1$, the judgment matrix is considered to be reasonable, otherwise the values of the elements of the judgment matrix are readjusted. In the same way, using the results and methods of single-level ranking, repeat the above steps, perform a comprehensive ranking of the secondary indicators in the evaluation layer, and obtain the weight of the secondary indicators.

For non-quantitative indicators such as technical readiness, difficulty of operation and management, or important indicators for which the amount cannot be obtained, it is necessary to carry out the standardized value of indicator evaluation. The index value is 0 point, 25 points, 50 points, 75 points, and 100 points, corresponding to 5 types of classifications: complex, more complicated, general, simpler, and simple.

After determining the tendency of various indicators, the maximum and minimum method is used to standardize the original data of the evaluation indicators, and the elimination dimension is normalized to the range of $[0,1]$, and a standardized decision matrix $\mathrm{Tmn}=[\mathrm{yij}] \mathrm{mn}$ is constructed.For each type of technology, according to the sequence of indicator data, the entropy weight method is used to determine the weight of each three-level indicator.

For each type of technology, according to the sequence of indicator data, the entropy weight method is used to determine the weight of each three-level indicator.From this, a hierarchical comprehensive evaluation model is established for evaluation, which is essentially a three-time weighted synthesis of indicators at all levels. The first two layers use subjective evaluation methods, and the third layer uses objective evaluation methods. The combination of expert experience and objective data ensures the scientificity and reliability of the results.

\subsection{Technology-Environmental Comprehensive Assessment Method}

Technology-environmental comprehensive assessment mainly adopts methods such as literature review, actual investigation, model construction, on-site measurement, and expert consultation. It determines the weight of each technology evaluation index, quantifies each technology evaluation index, and scores the evaluation index of each technology to obtain a comprehensive evaluation result.

Expert consultation mainly takes the form of questionnaire surveys, telephone consultations or faceto-face interviews, with the help of experts' personal knowledge and practical experience to carry out comprehensive assessments. The composition of the Liao River Basin Management Technical Expert Group is shown in Table 2.

Table 2.Composition of Liao River Basin Management Technical Expert Group

\begin{tabular}{|l|l|l|l|l|}
\hline source & $\begin{array}{l}\text { R \& D } \\
\text { institutions }\end{array}$ & $\begin{array}{l}\text { Univers } \\
\text { ity }\end{array}$ & $\begin{array}{l}\text { Business } \\
\text { unit }\end{array}$ & $\begin{array}{l}\text { Public } \\
\text { institutions }\end{array}$ \\
\hline $\begin{array}{l}\text { Number } \\
\text { of people }\end{array}$ & 10 & 9 & 9 & 8 \\
\hline
\end{tabular}

The Liao River Basin Risk Assessment Management Technology Assessment Index System includes two indicators, technology (A) and environment (B), and the weight results of the first-level indicators are shown in Table 3 below.

Table 3. First-level indicators and their weights

\begin{tabular}{|c|c|}
\hline First-level index & Weight \\
\hline technology & 0.5 \\
\hline environment & 0.5 \\
\hline
\end{tabular}

The technical indicators of the secondary indicators include two sub-indices of management operation and technical performance; the environmental indicators include two sub-indices of local protection and practical application. The weight results of the secondary indicators are shown in Table 4 below.

Table 4.Second-level indicators and their weights.

\begin{tabular}{|c|c|}
\hline Second -level index & Weight \\
\hline management operation & 0.5 \\
\hline technical performance & 0.5 \\
\hline local protection & 0.3 \\
\hline practical application & 0.7 \\
\hline
\end{tabular}

On this basis, management and operation indicators include three sub-indices: operational complexity (C1), operational safety (C2), and operational stability (C3);Technical performance indicators include three sub-indices of technical maturity (C4), process complexity (C5), and technological advancement (C6); Local protection indicators include two sub-indices of local policy improvement $(\mathrm{C} 12)$ and managerial quality improvement (C13);Practical application indicators include three sub-indices: excellent control list (C14), new detection method (C15), threshold or management level (C16). The weight results of the thirdlevel indicators are shown in Table 5 below. The entropy method is used to determine the weight of each thirdlevel indicator, and the calculation results are shown in Table 5 below. 
Table 5. Third -level indicators and their weights.

\begin{tabular}{|l|c|c|}
\hline Third -level index & Weight & $\begin{array}{c}\text { Final } \\
\text { weight }\end{array}$ \\
\hline Operational complexity & 0.2 & 0.05 \\
\hline Operational safety & 0.2 & 0.1 \\
\hline operational stability & 0.4 & 0.1 \\
\hline technical maturity & 0.4545 & 0.114 \\
\hline process complexity & 0.091 & 0.023 \\
\hline technological advancement & 0.4545 & 0.114 \\
\hline local policy improvement & 0.5 & 0.075 \\
\hline managerial quality improvement & 0.5 & 0.075 \\
\hline excellent control list & 0.333 & 0.117 \\
\hline new detection method & 0.333 & 0.117 \\
\hline threshold or management level & 0.333 & 0.117 \\
\hline
\end{tabular}

\section{Results and discussion}

In order to achieve the quantification of various evaluation indicators, with the help of fuzzy mathematics theory and the use of membership functions, the standardized evaluation values of various indicators of risk management technology are obtained.According to the risk management technology evaluation index system constructed in the previous article and the determined weights of each evaluation index, a comprehensive technology-environmental assessment of the risk management technology is carried out. The evaluation results are shown in Table 6 below.

Table 6. Evaluation results of water environment quality monitoring technical methods

\begin{tabular}{|c|c|c|c|c|}
\hline $\begin{array}{l}\text { First } \\
\text { level } \\
\text { index }\end{array}$ & $\begin{array}{l}\text { Third } \\
\text { level } \\
\text { index }\end{array}$ & $\begin{array}{c}\text { Third level } \\
\text { indicator } \\
\text { assignment }\end{array}$ & $\begin{array}{c}\text { Third level } \\
\text { indicator } \\
\text { score }\end{array}$ & $\begin{array}{c}\text { First level } \\
\text { indicator } \\
\text { score }\end{array}$ \\
\hline \multirow{6}{*}{ A } & $\mathrm{C} 1$ & 95 & 4.75 & \multirow{6}{*}{47.462} \\
\hline & $\mathrm{C} 2$ & 95 & 9.5 & \\
\hline & $\mathrm{C} 3$ & 98 & 9.8 & \\
\hline & $\mathrm{C} 4$ & 94 & 10.716 & \\
\hline & $\mathrm{C} 5$ & 96 & 2.208 & \\
\hline & C6 & 92 & 10.488 & \\
\hline \multirow{5}{*}{ B } & $\mathrm{C} 12$ & 95 & 7.125 & \multirow{5}{*}{29.097} \\
\hline & $\mathrm{C} 13$ & 90 & 6.75 & \\
\hline & $\mathrm{C} 14$ & 95 & 11.115 & \\
\hline & $\mathrm{C} 15$ & 96 & 11.232 & \\
\hline & $\mathrm{C} 16$ & 0 & 0 & \\
\hline
\end{tabular}

Table 7.Evaluation results of river basin water quality safety assessment and early warning management technology.

\begin{tabular}{|c|c|c|c|c|}
\hline $\begin{array}{l}\text { First } \\
\text { level } \\
\text { index } \\
\end{array}$ & $\begin{array}{l}\text { Third } \\
\text { level } \\
\text { index } \\
\end{array}$ & $\begin{array}{l}\text { Third level } \\
\text { indicator } \\
\text { assignment }\end{array}$ & $\begin{array}{c}\text { Third level } \\
\text { indicator } \\
\text { score }\end{array}$ & $\begin{array}{c}\text { First level } \\
\text { indicator } \\
\text { score }\end{array}$ \\
\hline \multirow{6}{*}{ A } & $\mathrm{C} 1$ & 96 & 4.75 & \multirow{6}{*}{47.085} \\
\hline & $\mathrm{C} 2$ & 94 & 9.5 & \\
\hline & $\mathrm{C} 3$ & 92 & 9.8 & \\
\hline & $\mathrm{C} 4$ & 94 & 10.716 & \\
\hline & $\mathrm{C} 5$ & 93 & 2.208 & \\
\hline & C6 & 95 & 10.488 & \\
\hline \multirow{5}{*}{ B } & $\mathrm{C} 12$ & 95 & 7.125 & \multirow{5}{*}{29.856} \\
\hline & C13 & 97 & 6.75 & \\
\hline & C14 & 0 & 11.115 & \\
\hline & C15 & 97 & 11.232 & \\
\hline & $\mathrm{C} 16$ & 96 & 0 & \\
\hline
\end{tabular}

Table 8. Evaluation results of water environment quality benchmark management technology.

\begin{tabular}{|c|c|c|c|c|}
\hline $\begin{array}{l}\text { First } \\
\text { level } \\
\text { index } \\
\end{array}$ & $\begin{array}{l}\text { Third } \\
\text { level } \\
\text { index } \\
\end{array}$ & $\begin{array}{l}\text { Third level } \\
\text { indicator } \\
\text { assignment }\end{array}$ & $\begin{array}{c}\text { Third level } \\
\text { indicator } \\
\text { score }\end{array}$ & $\begin{array}{c}\text { First level } \\
\text { indicator } \\
\text { score }\end{array}$ \\
\hline \multirow{6}{*}{ A } & $\mathrm{C} 1$ & 92 & 4.75 & \multirow{6}{*}{46.494} \\
\hline & $\mathrm{C} 2$ & 91 & 9.5 & \\
\hline & $\mathrm{C} 3$ & 92 & 9.8 & \\
\hline & $\mathrm{C} 4$ & 96 & 10.716 & \\
\hline & $\mathrm{C} 5$ & 94 & 2.208 & \\
\hline & C6 & 92 & 10.488 & \\
\hline \multirow{5}{*}{ B } & $\mathrm{C} 12$ & 93 & 7.125 & \multirow{5}{*}{17.94} \\
\hline & C13 & 91 & 6.75 & \\
\hline & C14 & 95 & 11.115 & \\
\hline & C15 & 0 & 11.232 & \\
\hline & C16 & 0 & 0 & \\
\hline
\end{tabular}

\section{Conclusions}

The research results show that the best technical indicator is the research management technology of water environment quality monitoring technology; the best environmental indicator is the management technology of the research project of water quality safety assessment and early warning management technology in the basin. The highest overall score is the water environment quality monitoring technology method research management technology. Each management technology has certain advantages, and the management technology should be used jointly. 


\section{Acknowledgments}

This research was funded by the China National Critical Project for Science and Technology on Water Pollution Prevention and Control (2018ZX07601001), and thank you for the help of all the teachers and students on the paper.

\section{References}

[1] Huang Tingting, Yuan Zhiqian, Hui Tingting. Determination of the weights of the evaluation index system of water environment management capacity based on analytic hierarchy process [J]. Environmental Protection and Circular Economy, 2016, 36 (11):66-69. (In Chinese)

[2] Wang Xuemei, Liu Jingling, Ma Muyuan. Water ecological risk assessment and management countermeasures of watershed [J]. Acta Scientiae Circumstantiae, 2010, 30(02):237-24. (In Chinese)

[3] Luo Hao, Huang Liang, Ma Yingyi, Xu Heng. Study on cumulative risk assessment of watershed water environment [J]. Environmental Science and Management, 2017,42(05):189-194. (In Chinese)

[4] Zhou Xiafei, Yu Fang, Liu Qi, Cao Guozhi, Ma Guoxia, Yang Weishan. Study on the risk zoning of sudden water pollution in the Dongjiang River Basin [J]. Acta Ecologica Sinica,2020,40(14):48134822. (In Chinese)

[5] Deng Xue, Li Jiaming, Zeng Haojian. Analysis of Analytic Hierarchy Process Weight Calculation Method and Its Application Research [J]. Mathematics in Practice and Knowledge, 2012, 42(07): 93-100. (In Chinese)

[6] Li Jipeng, Ma Li, Lu Zhiqiang. Using fuzzy analytic hierarchy process to optimize the advanced treatment plan of pulping and papermaking wastewater $[\mathrm{J}]$. Journal of Environmental Engineering, 2012, 6 (11): 4089-4096. 